\title{
The Resolution of Tax Disputes and International Tax Arbitration
}

\author{
Benjamí Anglès Juanpere 1
}

\begin{abstract}
Globalisation and the digital economy have revolutionised the world's markets and international transactions, some of which manage to escape national jurisdictions and bilateral treaties between States. With the lack of multilateral agreements, certain taxpayers, multinationals in particular, have managed to slip through the net of individual countries' tax regulations and been able to reduce their tax payments. To resolve tax disputes between taxpayers and States, with the chief goals of avoiding double taxation and not being subject to any tax jurisdiction, a number of multilateral measures have been instituted, including - amongst other mechanisms — binding international tax arbitration proceedings. The OECD and the $\mathrm{EU}$ are fostering the implementation of such measures, whose goal is to prevent tax avoidance and achieve a fair spread of tax burdens on an international level.
\end{abstract}

Index Terms - Tax regulations; Tax treaties; Tax disputes; International arbitration.

\section{INTRODUCTION}

In an increasingly globalised world, in which the explosion of the Internet has done away with physical borders, the possibility of doing business beyond local or even national markets has revolutionised international transactions and made their regulation necessary as a result. In this regard, the lack of any global international legal framework has been tackled, in the main, by the signing of bilateral tax treaties between countries aimed at providing legal coverage for such transactions.

Amongst the different aspects requiring regulation is the field of taxation, not only due to its repercussion and complexity, but also because of the unwanted consequences of applying the tax regulations of different legal systems to the same taxable events or activities. These undesirable consequences may arise for both taxpayers, who might be forced to pay tax twice on the same earnings, and for States, which may see their tax collection expectations negatively affected.

Globally, countries have already added arbitration clauses to newly negotiated tax treaties. Within the EU, the Arbitration Convention protects taxpayers in transfer pricing disputes, and the ECJ is called upon to decide tax treaty conflicts under recent tax treaties. Without doubting the ability of international tax arbitration, it has in practical terms played a significant role in resolving tax disputes. There are emerging new approaches to resolving

1 Published on January 24, 2020.

Benjamí Anglès Juanpere, University Oberta de Catalunya, Spain. (e-mail: bangles@uoc.edu) tax disputes including mandatory binding arbitration clauses in income tax treaties [1]

Despite the benefits of bilateral double taxation agreements in resolving tax disputes between taxpayers and the tax authorities of two countries, they may be insufficient or even inapplicable when faced with the behaviour of some taxpayers who, circumventing or abusing regulations, avoid their tax obligations.

There has been interest in resolving international tax disputes for a long time [2]. The International Fiscal Association (IFA) and the International Bar Association (IBA) and the International Chamber of Commerce (ICC) have been studying this matter in their meetings and conferences for years. After several attempts by different international bodies to resolve the issue, the Organisation for Economic Co-operation and Development (OECD) unveiled an Action Plan in 2013 to tackle the problems associated with tax base erosion and profit shifting (BEPS). This was carried out in the main by multinational companies, which were taking advantage of these very shortcomings in bilateral treaties and of the differences between national tax systems to avoid or reduce paying their taxes.

Implementing one of the actions contemplated in said plan, 2016 saw the creation of the Multilateral Convention to Implement Tax Treaty Related Measures to Prevent Base Erosion and Profit Shifting (MLI), with the goal of allowing signatory countries to complete and improve the agreements contained in bilateral double taxation conventions.

One of the mechanisms contemplated in the MLI is the implementation of international arbitration in cases in which mutual agreement procedures do not come to successful fruition. For it to be able to effectively accomplish its purpose, this arbitration must be mandatory and binding, and initiated at the request of the taxpayer.

Despite certain States' reticence to give up some of their sovereignty and be bound by the resolutions of bodies outside of their jurisdictions, the losses they are suffering in their tax income are forcing them to adopt new measures at an international level, as global problems can only be resolved effectively with multilateral solutions.

Among the international players, worthy of particular note is the European Union (EU), which approved in 2017 a Directive obliging Member States to introduce systems that must include binding arbitration in their legislation systems for resolving tax disputes and providing effective solutions outside of the national courts.

There were important changes introduced to international tax arbitration by the MLI and the EU Directive. Basically, more cases will be allowed for arbitration, proceedings will become more time-efficient and, the most important, arbitration or any other 
alternative dispute resolution will be mandatory. These changes in most detail are:

The time-frame is clearly established because the MLI and the Directive do not allow open-ended proceedings. Instead of that, the proceedings should be solved in shorter deadlines. In addition, under the Directive, the taxpayer may appeal to national courts in order to unlock the arbitration procedures.

- The scope is extended because more cases will be allowed for arbitration or any other alternative dispute resolution under the MLI and the Directive provisions, like double taxation issues or issues related to international tax treaties.

- The arbitration will be a mandatory second stage if a mutual agreement on tax issue is ineffective, and the decision by the arbitration panel will be binding for the states involved. Both changes will incentivize them to solve cases already at the mutual agreement procedure stage and to shorten proceedings. Besides, under the Directive, the taxpayer may force the decision's implementation by resorting to national courts.

- The new rules of the arbitration decision making model under the MLI and the Directive. There will be a final offer, or called as "baseball arbitration", by which the arbitration panel should decide between one of the offers presented by the states involved. In those cases, the substantiation or reasoning of decision is not needed, which means the arbitration method is quicker and effective than other.

With the arrival of new technologies and the strengthening of the digital economy, the world has completely changed and so, logically, the international rules must also fall into line with the new realities to ensure fairer and more balanced growth and distribution of global wealth. International tax arbitration can help achieve this, but this will depend upon the different international actors reaching an agreement and getting down to work.

\section{DOUBLE TAXATION AGREEMENTS}

Double taxation agreements (DTAs) between two countries have the aim of coordinating their respective tax administrations in the field of international tax treaties, so as to forge a common regulatory structure that permits the elimination of double taxation, and to avoid undesired effects upon both countries' tax revenues [3]. The elimination of double taxation has always been a leading concern amongst countries. The need to eliminate double taxation is indisputable, because it prevents the equitable international distribution of taxes, since a single taxable event cannot be subject to taxation twice due it its being linked with two different countries, be this because of its origin or to the residence of the taxpayer [4]. So, bilateral tax agreements contain provisions allowing for the deduction of taxes paid in another country, and the exemption for the payment of taxes for those earnings obtained in another country and subject to the taxes of that other country.

When it proves impossible to eliminate double taxation, the DTAs include mutual agreement procedures (MAPs) to resolve the associated conflicts. Nevertheless, many of these MAPs are not effective or their resolution takes too long, making it advisable to include arbitration clauses that permit the resolving of disputes when so decided upon by the affected parties [5]. For many years now, DTAs have been carrying out a truly important role from a tax perspective, as they permit the creation of a common legal framework between two countries and the development of mechanisms for establishing where each taxable event will be taxed. Nevertheless, given their bilateral nature, DTAs can only involve obligations between the signatories, and not third parties.

Over the course of time, this type of agreement has proved insufficient in preventing the behaviour of some taxpayers, who avoid their tax liabilities by abusing hybrid mismatches and the figure of the permanent establishment. Furthermore, it has also been seen how DTAs contain some overly simplistic application requirements and also suffer from some significant shortcomings that prevent the resolution of all types of tax disputes [6]. The types of conflicts covered by DTAs are: a) conflicts at source; b) jurisdictional disputes; c) conflicts of classification; d) conflicts around interpretation of the facts of the DTA's provisions CDI, and e) those regarding the application of internal regulations.

There is therefore a need for new tools to more effectively deal with the phenomenon of international double taxation and prevent double non-taxation (that is, not paying tax in any jurisdiction), thereby making it possible to tackle tax avoidance more effectively. The lack of a globally accepted set of rules to govern taxation has led to a very significant increase in cross-border tax disputes. Yet, little has changed in the way that governments try to resolve them, the mutual agreement procedures found in tax treaties are the main mechanism to resolve such disputes. Despite some improvements, processes handling is slow and the number of unresolved cases continues to grow, which has led to an increase in unrelieved double taxation. So, the international arbitration is the next step to resolve cross-border tax disputes [7].

The OECD aims to provide definitive solutions that change the all the deficiencies, gaps and inconsistencies in the worldwide tax framework by reformulating international taxation, such that the BEPS project represents a turning point in the history of international cooperation on taxation [8] and might be the greatest revolution in the international tax scene in the last twenty years [9]. In 2013, as part of the BEPS Project, the OECD unveiled an Action Plan dealing with the problems associated with tax base erosion and profit shifting, mainly carried out by multinationals taking advantage of these shortcomings and inconsistencies in DTAs and of the regulatory differences between national tax systems.

This plan consisted of fifteen actions or measures:

1) Address the tax challenges of the digital economy, by identifying the main difficulties that the digital economy poses for the application of existing international tax rules and developing detailed options to address these difficulties, taking a holistic approach and considering both direct and indirect taxation. 
2) Neutralise the effects of hybrid mismatch arrangements, by developing provisions and recommendations regarding the design of domestic rules to neutralise the effect of such arrangements (e.g. double non-taxation, double deduction and longterm deferral)

3) Strengthen CFC (controlled foreign company) rules by developing recommendations regarding the design of international tax transparency rules.

4) Limit base erosion via interest deductions and other financial payments, by developing recommendations regarding best practices in the design of rules to prevent base erosion through the use of interest expense, for example through the use of related-party and third-party debt to achieve excessive interest deductions or to finance the production of exempt or deferred income, and other financial payments that are economically equivalent to interest payments.

5) Counter harmful tax practices more effectively, with a priority on improving transparency, including compulsory spontaneous exchange on rulings related to preferential regimes, and on requiring substantial activity for any preferential regime.

6) Prevent tax treaty abuse, by developing model treaty provisions and recommendations regarding the design of domestic rules to prevent the granting of treaty benefits in inappropriate circumstances.

7) Prevent the artificial avoidance of permanent establishment status by developing changes to the definition of this status to prevent the artificial avoidance of PE status in relation to BEPS.

8) Assure that transfer pricing outcomes are in line with value creation by developing rules to prevent BEPS by moving intangibles among group members.

9) Assure that transfer pricing outcomes are in line with value creation by developing rules to prevent BEPS by transferring risks among, or allocating excessive capital to, group members.

10) Assure that transfer pricing outcomes are in line with value creation by developing rules to prevent BEPS by engaging in transactions which would not, or would only very rarely, occur between third parties.

11) Establish methodologies to collect and analyse data on BEPS and the actions to address it, by developing recommendations regarding indicators of BEPS' economic impact and ensuring that tools are available to monitor and evaluate the effectiveness of the actions taken on an ongoing basis.

12) Require taxpayers to disclose their aggressive tax planning arrangements, by developing recommendations regarding the design of mandatory disclosure rules for aggressive or abusive transactions, taking into consideration the administrative costs for tax administrations and businesses.

13) Re-examine transfer pricing documentation, by developing rules regarding transfer pricing documentation to enhance transparency for tax administration, taking into consideration the compliance costs for business.

14) Make non-judicial tax dispute resolution mechanisms more effective by developing solutions to address obstacles that prevent countries from solving treatyrelated disputes under MAPs.

15) Develop a multilateral instrument to enable jurisdictions that wish to do so to implement measures developed in the course of the work on BEPS and amend bilateral tax treaties.

As part of its implementation of this last action, in 2016, the OECD announced the Multilateral Convention to Implement Tax Treaty Related Measures to Prevent Base Erosion and Profit Shifting (MLI) with the clear goal of addressing the glaring shortcomings of DTAs. The convention's preamble recognises that "governments lose substantial corporate tax revenue because of aggressive international tax planning that has the effect of artificially shifting profits to locations where they are subject to nontaxation or reduced taxation".

The MLI is made up of 39 Articles, broken down into seven parts making up the treaty's text:

- Part 1: Scope and interpretation of terms.

- Part 2: Hybrid mismatches.

- Part 3: Treaty abuse.

- Part 4: Avoidance of personal establishment status.

- Part 5: Improving dispute resolution.

- Part 6: Arbitration.

Part 7: Final provisions.

The MLI is more ambitious than DTAs, as it is a more standardised tool and provides a response to the shortcomings of bilateral treaties, particularly with regard to regulation of the use of hybrid mismatch arrangements and the figure of the permanent establishment in thirdparty jurisdictions. This means that the coexistence of the MLI and existing DTAs will permit the implementation of the actions contemplated in the BEPS project without the need to renegotiate each of the bilateral tax treaties, thereby giving rise to the existence of two international treaties -one bilateral and the other multilateral- on the same tax matter.

This coexistence of treaties means, firstly, that any matters not contemplated in the MLI must be interpreted in accordance with the provisions of the DTA, which implies that the application of the MLI will only be possible when there is a bilateral tax agreement in force between two countries. And, secondly, with regard to all those matters that may be incompatible between the two treaties, it would be preferable to add a clause on the system for compatibility between them [10]. With it, perhaps being better to establish that the MLI will prevail over DTAs in such cases, without this meaning that the bilateral tax treaty cannot be applied should it provide better treatment for the issue [11].

Now, when successive treaties dealing with the same matter do not have the same countries as their parties, the previous treaties shall remain in force, so long as both of a DTA's two signatory countries do not adhere to the MLI, and solely the terms of the bilateral agreement shall be enforceable. Thus, the countries adhering to the MLI will have to "convince" other countries with which they have bilateral tax agreements to do likewise because, if not, the provisions of the multilateral agreement shall be inapplicable from an international tax law standpoint [12].

In this regard, it turns out that OECD Member States are being slow to sign up to the MLI, given that currently only 15 of the 85 have actually signed and deposited the 
ratification instrument, meaning that many countries still have to ratify the instrument and become fully involved in enforcing it [13]. So, with regard to the treatment and resolution of tax disputes, the time passing between the adhesion of different countries to the MLI and the effective enforcement of its provisions will entail a significant delay in the implementation of BEPS project measures across OECD Member States [14].

Whatever the case, the transition from a model based exclusively on bilateral treaties to one using multilateral agreements between a number of countries entails greater unification of their tax regulations as a whole and better adaptation into line with a constantly changing global context. In turn, multilateral treaties provide more and better measures in the fight against fraud and tax avoidance, particularly in cases of triangular relationships [15], such as those of abuse of double residence or the figure of the permanent establishment [16]. Multilateral treaties represent an improvement over DTAs because the latter are not coordinated and do not help improve the single market, fail to foster countries' economic integration, do not guarantee uniform interpretation of regulations and are also not effective in the fight against tax evasion [17].

For all these reasons, multilateral treaties like the MLI are crucial in resolving tax conflicts between countries, be this because DTAs are insufficient or because such agreements do not exist between some countries. Of those mechanisms included in the MLI for resolving such conflicts, worthy of particular note are tax dispute resolution mechanisms and the international tax arbitration procedure.

\section{TAX DISPUTE RESOLUTION MECHANISMS}

The international tax disputes arise in two general contexts: the first involves one or more taxpayers on one side and the government on the other side. In these disputes, the taxpayers usually resist the imposition of taxes which government claims are owed. The second type of disputes involves two or more governments arguing over the allocation of tax revenues derived from trade and investment transactions between their territories [18].

The MLI plays a key role in establishing tax dispute resolution systems at a cross-border level. The fact is that, with the booming global economy, there is an increasing need for mechanisms such as multilateral treaties to help swiftly and expeditiously resolve any tax disputes arising within the field of international relations. For Altman (2006): "tax treaties are unique in a way that makes the comparison with trade treaties rather constrained. Unlike trade agreements, tax treaties are designed to have direct effect under domestic laws; thus, even in dualistic legal systems, taxpayers are able to enforce treaty obligations through the use of domestic courts. Taxpayers are therefore afforded much more protection under tax treaties than under most other international treaties, and the need for a binding international procedure is weaker" [19].
Bravo (2019) explains that MLI establishes the mandatory binding arbitration procedure. Since no consensus was reached among the participants in the BEPS project on the adoption of the mandatory binding arbitration procedure as a mechanism to censure the timely resolution of MAP cases, the treaty makers of MLI designed flexible provisions for its implementation. However, the MLI achieves a coordinated effect in regard to the implementation of the mandatory binding arbitration procedure, in spite of the high level of flexibility offered to its parties [20].

In any case, within the framework of the MLI, it is extremely important that tax authorities of different countries can agree on decisions made and establish common guidelines which can guarantee an objective view and application of tax agreements. This will serve to deal with any tax disputes that may arise when it proves impossible to resolve them using any of the following dispute resolution mechanisms.

\section{A. Mutual agreement procedure (MAP)}

One of the tax dispute resolution mechanisms contemplated in the MLI is the mutual agreement procedure or MAP. When a person considers that the measures adopted by one of the signatory countries entails or may entail for that person taxation not in accordance with the provisions of the tax agreement, that person may present the case to the competent authority of either of the signatory States within three years from the first notification of the action resulting in taxation not in accordance.

If the objection appears to be justified and if it is not itself able to arrive at a satisfactory solution, the competent authority shall endeavour to resolve the case by mutual agreement with the competent authority of the other signatory country in order to avoid taxation that is not in accordance with the tax agreement. Any agreement reached shall be implemented notwithstanding any time limits in the domestic law of the signatory countries.

The MAP's key elements are [21]:

- The competent authority receiving the initial complaint has no obligation to accept the complaint.

- Contacts under the MAP are purely between the governments. The taxpayer raising the complaint is not a party and has no right to appear or make submissions to the competent authorities.

- The governments negotiations are confidential, even to the taxpayer raising the complaint.

- There are no specific time limits within which the competent authorities have to act.

- $\quad$ There is no obligation on each competent authority to reach an agreement that avoids double taxation.

- The result of the competent authority negotiation is confidential, except for the taxpayer raising the complaint.

In any case, the competent authorities of the two countries shall endeavour to resolve by mutual agreement any difficulties or doubts arising as to the interpretation or application of the tax agreement(s). They may also consult together for the elimination of double taxation in cases not provided for in said agreements. With these objectives in mind, the countries shall ensure the 
enforceability of the MAP, guaranteeing that: 1) the authorities ensure the access of persons and business to the MAP, removing any barriers to solving tax agreement-related disputes by means of said procedure; 2) the authorities make sure that the obligations regarding the MAP are applied in good faith, and 3) the authorities ensure that their respective tax-related administrative procedures avoid, as far as possible, any conflicts with the tax agreements.

One important aspect of the MAP is the duty of countries to uphold and promote transparency at all times, a key aspect in ensuring that said procedure always enjoys the greatest possible credibility as a tool for resolving tax disputes. Kollmann and Turcan (2015) consider the MAP "provides taxpayers with an alternative to tax litigation, which can be cumbersome and uncertain, especially since it needs to be taken up in both of the contracting states in order to provide an effective relief for double taxation. It also entails a timing advantage, since the taxpayer is not obliged to wait until the taxation has been charged or notified to him in order to set the procedure in motion. It is sufficient if he establishes that the actions of one or both contracting states will probably result in taxation not in accordance with the convention" [22].

Although playing an important role in resolving tax disputes arising from DTAs, MAPs have, unfortunately, proven to be insufficient for such purposes. The causes of this inadequacy would succinctly be [23]:

- The lack of any obligation for competent authorities to reach agreement, resulting in complete absence of any legal certainty for taxpayers, given the dearth of any guarantee of reaching a solution regarding the issue raised.

- It does not contemplate the direct involvement of the taxpayer in the procedure.

- The slowness and excessive duration of the procedure.

- $\quad$ The lack of uniformity with regard to the publication of the resolution adopted.

- The absence of any resources guaranteeing enforcement of the resolution adopted.

- The scant information on its workings and the general lack of interest on the part of countries in the MAP.

Additionally, the bilateral nature of the MAP represents a significant limitation in a globalised environment with multiple potentially affected jurisdictions. Given all of this, there is a need for different alternative or complementary mechanisms that permit resolution of those issues that overwhelm or do not fit with the MAP [24].

\section{B. Correlative adjustments}

Amongst these other mechanisms, the MLI establishes that of the correlative adjustment, applicable in those cases in which the business's profits, taxed by a country, include the profits obtained by another business in another country signatory to the agreement, which had already been subject to taxation in said other country. In such cases, the tax authority of the country in which the included profits are declared shall carry out the applicable correlative adjustment in the amount of the tax already levied upon said profits in the other country.

This adjustment is bilateral: in other words, together with a positive adjustment in one business (i.e. the increase in its taxable base) a negative adjustment is made in the other (i.e. a reduction in its taxable base or correlative adjustment), with the aim of consistently distributing the profits between the two countries. In any case, such adjustments are made to the tax bases and for tax purposes and have no impact upon the businesses' accounts. The fact of there being differences between businesses' tax and accounting treatments does not entail any irregularity or non-compliance, given that each of them arise from the application of the regulations for each particular field. In any case, for Trapé Viladomat (2009), tax adjustments "do not constitute any risk of erosion of taxable bases, in Spain at least. Remember that the design, at least, of the Corporate Income Tax declaration means that tax adjustments are completely transparent for the Spanish administration, which can detect them easily and check them to ascertain whether they comply with or violate the principle of free competition" [25].

With regard to the repatriation of profits, taxpayers can be relieved of certain secondary tax consequences of transfer profit adjustments by establishing (and satisfying) intercompany accounts receivable in favour of the taxpayer, to which an income allocation is made, and corresponding accounts payable from the commonly controlled taxpayer, where the correlative adjustment is made.

Although correlative adjustments may be easily understandable on a conceptual level, they are not so understandable when it comes to a transaction between two different jurisdictions, since, despite the attempts to harmonise internal regulations, in the end, each country will exercise its fiscal sovereignty in providing for its own transfer pricing policy, which shows the importance of international treaties and of including specific clauses permitting the resolution of this kind of conflict.

Besides, the introduction of a correlative adjustment mechanism for allocation of profits between a head office and a permanent establishment, based on transfer pricing concepts, is an important feature in the opinion of Garbarino (2017). He considers if there is a transfer pricing allocation in a contracting state, adjustments must be made in the other contracting state. This would confirm the relevance of the purpose of the elimination of double taxation, when the allocation is respected in the residence and source country. However, he also affirms that the correlative adjustments in the new Directive are not binding insofar as there is no arbitration, while an effective resolution of the dispute would require a binding MAP or any tax arbitration procedure [26].

\section{International tax arbitration}

International tax arbitration is another mechanism for resolving conflicts involving a clash between the tax legislations of two or more countries. Generally, arbitration is an alternative out-of-court dispute resolution method in which the parties agree to submit their dispute to the decision of a neutral third party of their choosing. As Harwood (2017) says, international arbitration has 
grown in importance in the last few decades, in tandem with globalisation. This is for several reasons. Most importantly, arbitration works. According to a recent survey of major global corporations, arbitration is the most favoured dispute resolution mechanism for international matters (ahead of court litigation, mediation, adjudication and expert determination), whether as claimants or respondents. [27].

On an international level, it is more difficult to find supra-state institutions and so the use of international arbitration may be a good solution for efficiently resolving such conflicts. Some time ago, Hortalà i Vallvé (1996) asserted "arbitration is the mechanism that helps overcome the obstacles arising from the lack of agreement between countries. When disputes cannot be solved by national jurisdictions and attempts at a diplomatic outcome are not particularly encouraging, arbitration appears an alternative for efficiently unblocking the way forward and for providing a neutral solution to the issue raised" [28].

There is undoubtedly a wide range of scenarios in which arbitration can be used as a dispute resolution mechanism, but it is particularly suited to the field of taxation given the lack of international tribunals in the field. So, with the passing of time, international tax arbitration will increasingly be seen as a valid cross-border tax dispute resolution system, thanks to which countries may settle their differences with some degree of assurance because international tax arbitration does not clash with the principle of legality and helps to break the deadlock between the jurisdictions of the two countries involved. Additionally, arbitration achieves more efficient tax dispute resolution than resorting to the judicial system, as its outcome complies with the law and is fairer to the taxpayer [29].

Nevertheless, to be fully enforceable, the arbitration proceedings must be binding. With this in mind, the MLI includes clauses on arbitration, establishing the obligation to resolve tax disputes between jurisdictions by means of an international arbitration mechanism, often not included in the DTAs, which, in addition to facilitating conflict resolution, gives legal security to the tax dispute resolution procedure. The inclusion of arbitration clauses is also a plus because it breaks the mould of the bilateral legal framework governing the two jurisdictions signatories to a DTA and allows multiple countries to subject themselves to common international regulations, thereby achieving a degree of uniformity between a good number of countries. Additionally, from an economic standpoint, turning to international arbitration to resolve conflicts could prove much more beneficial than subjecting themselves to the courts, as it allows them to obtain resolutions that are equally satisfactory in legal terms but at a lower cost in terms of both time and money.

When a person considers that the actions of one or both of the jurisdictions that are signatories to the DTA result or will result for that person in taxation not in accordance with the provisions of said agreement, that person may submit a claim within three years of receipt of the first notification of the matter in dispute. If the competent authorities of contracting jurisdictions reject the claim or do not reach agreement on resolving the matter pursuant to the provisions of the DTA, they shall have a period of two years to resolve it by mutual agreement. If said period expires without agreement being reached, the issue shall be submitted to arbitration if the affected person so requests.

Nevertheless, delimiting the objective scope of arbitration is not easy because it can vary between countries. Whilst some countries prefer to limit its application to specific purely practical articles, such as those on permanent establishments or transfer pricing, others choose to exclude from its scope cases in which, for tax policy reasons, they do not wish to impose upon them an unconnected solution with any bilateral negotiations which their competent authorities may be undertaking [30].

Once arbitration has been requested, the body in charge thereof shall be the arbitration panel, made up of three individual members with expertise or experience in international tax matters. Each of the contracting jurisdictions shall appoint one member, and the two members so appointed shall choose a third member who shall serve as chair of the arbitration panel. The possibility of the taxpayer being able to participate in the choice of arbiter would appear to be completely excluded since the two affected jurisdictions are the only parties to the procedure, although this is without prejudice to it participating during the arbitration proceedings. For its part, the chair shall not be a national or resident of either contracting jurisdiction. In any case, all panel members shall be subject to the principle of confidentiality.

After the panel is constituted, tax authorities of the two jurisdictions shall submit, in the established period of time, any documents and submissions they deem fit, or requested by the panel, and which set out their positions and proposed resolution with regard to the issue raised, sharing them with the other party so that it may respond in due time and form as it deems best fit.

In light of the information and documentation submitted, the arbitration panel shall reach a decision. In this regard, the panel has the power to select as its decision at least one of the proposals submitted. The arbitration panel's decision shall be binding on all parties and shall be implemented through a mutual agreement, unless:

- The person directly affected by the case does not accept the mutual agreement that implements the arbitration decision.

- The person directly affected by the case pursues litigation on the issues which were resolved in the mutual agreement implementing the arbitration decision in any court or administrative tribunal.

- A final decision of the courts of one of the contracting jurisdictions holds that the arbitration decision is invalid.

Nevertheless, the arbitration proceedings may conclude before the panel issues its decision, when:

- The person who presented the case withdraws the request for arbitration.

- The competent authorities of the contracting jurisdictions reach a mutual agreement to resolve the case.

- A court or administrative tribunal of one of the contracting jurisdictions issues a ruling on the issue first. 
With regard to international tax arbitration proceedings, Almeida (2018) concludes: “As taxpayers and states search for an adequate remedy for international tax claims, the parties should use the investment arbitration model as a basis. It has demonstrated success as a dispute resolution method and reflects changes in the economic relationship between private parties and states. Investment arbitration has moved away from diplomatic protection toward granting private parties the same status. In the case of tax arbitration, more substantial participation by taxpayers in the arbitral procedure remains a matter of state policy. However, states can grant and define the amount of access taxpayers have to the dispute. By including taxpayers in the dispute procedures, states would solve the issue of award enforcement, avoiding handling arbitration and domestic litigation, and increase the perceived fairness of the system" [31].

\section{ARBITRATION IN THE EUROPEAN UNION}

The European Commission is the main driving force behind tax arbitration within the EU, with the aim of providing solutions in cases of double taxation involving community citizens and businesses, something that occurs when two Member States both claim the right to tax the same profits and earnings of a single taxpayer. One this matter, Almeida (2018) reminds that "tax administrations have also expanded their taxation powers across borders, touching legal transactions that relate to the state in any way (...) No international law imposes limits on what a state can consider a taxable event, so more than one state can claim that a legal transaction is connected to its country, thereby leaving taxpayers at risk of being taxed by multiple countries for the same transaction" [32]. Double taxation represents an obstacle to individuals and businesses operating on a cross-border level, creating an excessive tax burden that may reduce competitiveness and scare off investors.

By 1990, the European Union had already seen the approval of Convention 90/436/EEC, on the elimination of double taxation in connection with the adjustment of profits of associated enterprises. I was known as the EU Arbitration Convention, as it incorporated for the first time, arbitration as a conflict resolution mechanism in the field of double taxation. Nevertheless, the Convention's effectiveness was always limited, firstly, given the restricted scope of its application and, secondly, because it was never ratified by all Member States. In opinion of Herrera Molina (2010), "international double taxation constitutes a clear obstacle to the exercising of Community freedoms, as it actually discriminates those exercising them. Therefore, if Member States are unable to eliminate it, Community institutions will have to act (inverse subsidiarity) and if the latter do not do so, a breach of Community law would occur which should be dealt with by the Court of Justice" [33].

In light of the increased tax-related litigiousness between Member States and the lack of effective associated resolution mechanisms beyond bilateral agreements, 2002 saw the creation of the EU Joint Transfer Pricing Forum, which drew up a non-binding code of conduct that established the bases for tax arbitration, limited to eliminating double taxation of associated related undertakings and their permanent establishments. Nevertheless, its implementation was again poor given its limited and non-compulsory nature.

Following the OECD initiative mentioned earlier and the roll-out of the BEPS project, the European Union has finally taken on board the fact that it must tackle the shortcomings and gaps in the existing Community-wide tax dispute resolution mechanisms, which are fundamentally bilateral in nature. Accordingly, the Council approved Directive (EU) 2017/1852 of 10 October 2017 on tax dispute resolution mechanisms in the European Union on taxes on income and capital, which establishes the obligation for Member States to implement and develop a tax dispute resolution system that includes arbitration to achieve enforceable and binding out-ofcourt solutions.

For Perrou (2019), the adoption of this Directive constitutes a major step forward as far as international tax treaty dispute resolution is concerned. The new instrument not only lays down effective procedures for the resolution of tax disputes, it also lays down the rights and obligations of the taxpayers, with an explicit acknowledgement in Recital 9 of the Directive [34],

There were some reasons for the approval of this Directive: to begin with, there was the need to implement the provisions of BEPS Action 14 in the European Union; also important were Europe's will to limit bilateral clauses on mutual procedures, generally included in DTAs, and, lastly, there was the pressure from multinationals to achieve a quick, safe, amicable and cheap solution to dispute with the different tax administrations. In any case, the Directive's resolution mechanisms will be applicable to disputes arising from the interpretation of DTAs, difficulties during their applications, or when double taxation problems occur with regard to the aforementioned taxes.

The key benefits of this Directive are [35]:

A guaranteed outcome within fixed timeframe. If the tax authorities do not resolve the dispute within six months of receipt of the complaint, they should resolve the dispute by a mutual agreement procedure within two years after acceptance of the complaint. Thereafter, taxpayers can submit their unresolved case to arbitration. Then, the dispute will be resolved by an advisory commission, chaired by a judge and composed of independent persons. No later than six months, the commission should solve the dispute. Its opinion will be binding for the authorities.

- A broad scope. The new mechanism is not limited to double taxation issues, dual residences or attribution of profits to permanent establishments. Taxpayers (companies and individuals) can submit any complaint to Member State's tax authority about the interpretation and application of the EU Arbitration Convention and of intra-EU tax treaties.

- A process driven by the taxpayer. The complaint must be submitted within three years after notification of the tax assessment, tax audit report or any other action that results in a tax dispute. The complaint can be pursued in parallel with domestic remedies. If the tax authorities unduly delay the procedure, the taxpayer can go to the Luxembourg 
courts and appeal a denial of a complaint or claim the enforcement of a decision.

The preamble to the Directive acknowledges the shortcomings of the mutual agreement procedures of bilateral treaties, as well as of the aforementioned Arbitration Convention of 1990, and that there is a crucial need to introduce an effective and efficient framework for the resolution of tax disputes which ensures legal certainty and a business-friendly environment for investments in order to achieve fair and efficient tax systems in the Union. These mechanisms should also create a harmonised and transparent framework for solving disputes and thereby provide benefits to all taxpayers

To this end, the tax authorities of each country must, firstly, implement preventative measures to avoid the appearance of conflicts between the provision of tax agreements and their domestic law. Secondly, they must encourage the amicable resolution of tax disputes and, lastly, they must establish an arbitration procedure that permits the speedy and effective resolution of tax disputes outside of the justice system.

In the case of double taxation within the European Union, the tax dispute resolution system provided for by the European Commission is characterised by:

- The obligation on the part of Member States to establish this system to resolve all disputes arising within the framework of DTAs affecting the tax position of Community citizens and businesses.

- The scope of this system, which covers all types of disputes arising from DTAs and other international agreements, with the goal of eliminating the double taxation of Community citizens and businesses.

- The division of the resolution process into two stages, the first involving a mutual agreement procedure and the second arbitration.

- The possibility of taxpayers' direct participation in the procedure.

- The possibility of taxpayers lodging appeals before the courts of justice at any time, for the purpose unblocking the procedures.

- The obligation to notify taxpayers of resolutions and to public summaries of arbitration findings.

The mechanisms contemplated by the Directive that can be used by the parties are truly lax, permitting processes both consensual (mediation and conciliation) and compulsory (arbitration) [36]. In this regard, the Directive prefers the implementation of the former in the first stage, with the aim of achieving mutual agreement between the parties, and only subsequently, when it has proved impossible to reach agreement, is it possible to resort to the mechanism of arbitration.

Firstly, the taxpayer will present a complaint before the relevant Member State authorities so that they may issue a resolution. When the competent authorities of the Member States concerned decide to accept the taxpayer's complaint, they shall initially endeavour to resolve the question in dispute by means of a mutual agreement procedure, whose resolution deadline shall be two years from acceptance of the complaint. Once the competent authorities of the Member States have reached an agreement as to how to resolve the question in dispute, said agreement shall be notified without delay to the affected person, as a decision that is binding on the authority and enforceable by the affected person, subject to the affected person accepting the decision and renouncing the right to judicial proceedings.

Where the competent authorities of the Member States concerned have not reached an agreement on how to resolve the question in dispute within the established period, the affected person shall be informed, indicating the general reasons for the failure to reach agreement. It is at this point that the taxpayer may decide whether to request arbitration.

Upon a request made by the taxpayer, the competent authorities of the Member States concerned shall set up an advisory commission comprising one representative of each State, one independent person of standing, also appointed by each State by means of a special process, and by a chair chosen by the above, who shall, unless otherwise agreed, be a judge. Regarding the composition of the advisory commission, each State should draw up a list of representatives, who would be members of their tax administrations, and another list of independent persons of standing with competence in the field, choosing its members from these two lists [37]. After its constitution, the same authorities shall notify the taxpayer of the commission's rules of functioning, including the characteristics of the dispute, the proceedings' timeframe, the composition of the commission, the rules governing the affected persons' participation in the proceedings and any others deemed relevant.

All the parties shall provide the commission with any information, evidence or documents that may be relevant for the resolution. In this regard, the affected persons may request to appear before the commission or do so at the latter's request. To implement the exchange of information, in addition to the information exchange clauses included in most bilateral agreements, of great assistance is Council Directive 2011/16/EU of 15 February 2011 on administrative cooperation in the field of taxation, governing the three classic types of information exchange: exchange of information on request, spontaneous exchange of information and automatic exchange of information. The international regulations pay particular attention to the exchange of information on request, which is the type most implemented in practice, especially in double taxation procedures.

Within six months, extendable by three further months, the advisory commission must deliver its opinion to the competent authorities of the Members States concerned. The opinion shall be adopted by simple majority of its members, with the chair having the casting vote in the case of a tie. One innovative aspect of the Directive is concerned with the decision-making process, which, for the first time, includes the "final offer" model of arbitration, also dubbed "baseball arbitration". With this method, the commission merely has to choose one of the proposals submitted by the Member States' tax authorities. There is no need to explain the bases of its decision or complement it with any supporting arguments. As a result, the resolution mechanism shall, in such cases, be quicker and more cost-effective.

The competent authorities shall agree on how to resolve the question in dispute within six months of the 
notification of the opinion of the advisory commission. If they fail to reach an agreement as to how to resolve the question in dispute, they shall be bound by that opinion. Whatever the case, the final decision on the resolution of the dispute shall be notified to the affected person without delay and shall be binding on the Member States concerned and implemented subject to the affected person(s) accepting the final decision and renouncing the right to judicial proceedings within the established timeframe.

Lastly, the competent authorities may agree to publish the final decision subject to consent of each of the affected persons. If they do not give their consent, the competent authorities shall publish an abstract thereof. Although the commissions' decisions do not set a precedent, their content shall be illustrative and serve as a guide for taxpayer behaviour in the future.

The deadline for Member States to transpose this Directive is 30 June 2019, and it shall be applicable to complaints submitted on or after the following 1 July, meaning it is not yet possible to gauge the measure's effectiveness. In this regard, Article 21 of the Directive establishes that the commission shall evaluate its implementation and shall present a report by 30 June 2024. Nevertheless, the introduction of new alternative procedures for resolving cross-border tax disputes guaranteeing both the legal certainty of the procedure and the enforceability of the decision may provide a suitable complement to existing mutual agreement procedures, permitting satisfactory closure for tax-related disputes without the need to resort to the courts.

\section{CONCLUSIONS}

The appearance of new technologies, the globalisation of markets and the digital economy have caused a revolution in international transactions, forcing countries to redefine their relations and agree on new regulations in all fields, particularly on taxation, given the shortfalls and weaknesses of existing bilateral agreements and the national legislation systems which allow some taxpayers, especially multinationals, to avoid or reduce their tax payments.

Double taxation agreements between States, which were effective for a time, have proven to be insufficient in providing a response to all disputes and, especially, the abuses of some taxpayers of tax mismatches and the figure of the permanent establishment. Meaning there is a need to go beyond the bilateral nature of the treaties and promote multilateral agreements in response to these new global challenges.

The inclusion in such multilateral agreements of structured mechanisms for the resolution of tax disputes, outside of the judicial system, creates greater opportunities for taxpayers and tax authorities to resolve their disputes and avoid the undesirable consequences of double taxation or of not being subject to any tax jurisdiction.

The main dispute resolution mechanisms are: a) Mutual Agreement Procedure (MAP); b) Correlative adjustments, and c) International Tax Arbitration. In any case, within the framework of the MLI, it is very important that the different tax authorities can agree on decisions made and establish common guidelines to guarantee the application of tax agreements.

The Mutual Agreement Procedure used in inernational tax disputes allows competent authorities from governments of contracting states to interact with the intent to resolve those disputesm, which usually involve cases of double taxation where the same profits have been taxed in two different jurisdictions. However, the bilateral nature of the MAP represents a significant limitation in a globalised environment with multiple potentially affected jurisdictions.

In the other hand, the correlative adjustments are bilateral adjustments applicable in those cases in which the business's profits, taxed by a country, include the profits obtained by another business in another country signatory to the agreement, which had already been subject to taxation in said other country. Together with a positive adjustment in one business (increasing its taxable base) a negative adjustment is made in the other (reducting its taxable base through a correlative adjustment), with the aim of distributing the profits between the two countries

There is also the International Tax Arbitration, which makes it possible to achieve a solution to tax disputes involving two or more countries outside of national court systems, although its implementation must be binding and transparent to be fully effective. It is difficult to find international institutions to resolve such conflcts, for that reason this mechanism is particularly suited to the field of taxation given the lack of international tribunals in this field.

The OECD, at a worldwide level, and the EU, at a European one, have promoted a range of measures to encourage the resolution of tax disputes, including international tax arbitration. Whilst the former has promoted the creation of a multilateral treaty to resolve the problems associated with tax base erosion and profit shifting, including a compulsory arbitration clause; the second one has approved a Directive to force Member States on this issue.

Under the Council Directive (EU) 2017/1852, of 10 October 2017, on tax dispute resolution mechanisms in the European Union on taxes on income and capital, the Member States have the obligation to implement and develop a tax dispute resolution system that includes arbitration to achieve enforceable and binding out-ofcourt solutions.

In both cases, arbitration takes place after the failure of mutual agreement procedures and it is offered to the taxpayer as an alternative to a judicial action. Its binding nature for jurisdictions but not for the taxpayer, who can resort to the courts if they disagree with the resolution, makes it potentially attractive as an alternative resolution method.

Presently, only a few countries have ratified the MLI, and only a few EU Members States have recently approved regulations complying with the above Directive, which will not be evaluated by the Commission until 2024. So, although it is still too early to reach any conclusions about their effectiveness, the way forward has already been mapped out and the will of most of the international community to tackle the tax avoidance, 
stemming from globalisation and digital economy, seems a firm purpose.

\section{REFERENCES}

[1] N. Quiñones, "International Tax Arbitration and the Sovereignty Objection: The South American Perspective," Tax Notes International, no. 11, pp. 533-542, 2008.

[2] G. Lindencrona and N. Mattsson, Arbitration in Taxation. Netherlands: Kluwer, 1981, pp. 76-82.

[3] D.M. Ring, "International Tax Relations: Theory and Implications," Tax Law Review, no. 60, pp. 83-154, Jan. 2007.

[4] N. Sánchez García, "La doble imposición internacional," Revista de treball, economia i societat, no. 16, pp. 25-40, Jan. 2000.

[5] M. Lang and B. Wiman, "Conference on arbitration in tax treaty law - Uppsala University," Intertax, vol. 42, no. 3, p. $202,2014$.

[6] F. Serrano Antón, La resolución de conflictos en el Derecho Internacional Tributario: procedimiento amistoso y arbitraje. Spain: Civitas-Thomson Reuters, 2011.

[7] M. Lang and J. Owens, International Arbitration in Tax Matters. Austria: Lang \& Owens Eds., 2016.

[8] A. Ribes Ribes, "Técnicas arbitrales en los convenios de doble imposición: El borrador de la International Fiscal Association de 27 de septiembre de 2002," Crónica Tributaria, no. 109, pp. 137-150, 2003.

[9] R.S. Avi-Yonah and O. Halabi, "A Model Treaty for the Age of BEPS," University of Michigan Public Law \& Legal Theory Research Paper, no. 411, pp. 1-41, 2014.

[10] J. Malherbe, "The issues of dispute resolution and introduction of a Multilateral Treaty," Intertax, vol. 43, no. 1, pp. 91-95, 2015.

[11] Developing a Multilateral Instrument to Modify Bilateral Tax Treaties, OECD/G20. Base Erosion and Profit Shifting Project. Paris, France: OECD Publishing, 2015.

[12] R.S. Avi-Yonah, "Hanging Together: A Multilateral Approach to Taxing Multinationals," Michigan Business \& Entrepreneurial Law Reviews, vol.5, no. 137, pp. 137-159, 2016.

[13] J. Schwartz. (September 2015). Multilateral Tax Treaty: if we build it, will they come? Kluwer International Tax Blog [Online]. Available: http://kluwertaxblog.com/2015/09/05/multilateral-tax-treaty-ifwe-build-it-will-they-come/

[14] R. Eicke, "A BEPS Multilateral Instrument - Practical Solution or Elusive Pipe Dream?", Tax Notes International, no. 10, p. 528, 2014.

[15] E. Fett, Triangular Cases. The Application of Bilateral Income Tax Treaties in Multilateral Situations. Austria: Lang \& Owens Eds., 2014.

[16] P. Arginelli, "The Discriminatory Taxation of Permanent Establishment by the Host State in the European Union: a Too Much Separate Entity Approach," Intertax, vol. 35, no. 2, pp. 82-116, 2007.

[17] G. Zhai, "Triangular Cases Involving Income Attributable to Pes," Tax Notes International, no. 12, pp. 1105-23, 2009.

[18] C. Irish, "Private and Public Dispute Resolution in International Taxations," Contemporary Asia Arbitration Journal, vol. 4, no. 2, pp. 121-144, 2011.

[19] Z.D. Altman, Dispute Resolution under Tax Treaties. Netherlands: IBFD Publications, 2006

[20] N. Bravo, "Mandatory Binding Arbitration in the BEPS Multilateral Instrument," Intertax, vol. 47, no. 8/9, pp. 693-714, 2019.

[21] C. Irish, "Private and Public Dispute Resolution in International Taxations," Contemporary Asia Arbitration Journal, vol. 4, no. 2, pp. 121-144, 2011.

[22] J. Kollmann and L. Turcan, "Overview of the Existing Mechanisms to Resolve Disputes and Their Challenges", International Arbitration in Tax Matters. Austria: Lang \& Owens Eds., pp. 15-76, 2015.

[23] A. Ribes Ribes, "Técnicas arbitrales en los convenios de doble imposición: El borrador de la International Fiscal Association de 27 de septiembre de 2002," Crónica Tributaria, no. 109, pp. 137-150, 2003.
[24] A. Martín and J.M. Calderón, "El Plan de Acción de la OCDE para eliminar la erosión de las bases imponibles y el traslado de beneficios a otras jurisdicciones," Quincena Fiscal, no. 1-2, pp. 110-111, 2014

[25] M. Trapé Viladomat, "Ajustes correlativos. Procedimiento amistoso y arbitral," Fiscalidad de las operaciones vinculadas. Spain: CISS-Wolters Kluwer, pp. 519-549, 2009.

[26] C. Garbarino. "Tax Treaty Disputes in Italy," A Global Analysis of Tax Treaty Disputes. UK: Cambridge University Press, 2017.

[27] S. Harwood, An introduction to international arbitration. London, UK: Stephenson Harwood LLP, 2017.

[28] J. Hortalà i Vallvé "El arbitraje en materia tributaria. Un análisis crítico del Convenio de la Unión Europea," Crónica Tributaria, no. 79, pp. 55-66, 1996.

[29] A.P. Dourado and P. Pistone, "Some critical thoughts on the introduction of arbitration in tax treaties," Intertax, vol. 42, no. 3, pp. 158-160, 2014

[30] M. Barreno Asension, "Nuevos retos del arbitraje fiscal internacional". Cuadernos de Formación, vol. 21, pp. 27-41, 2017.

[31] G. Almeida, "Should Taxpayers Have Access to the International Tax Arbitration Procedure?", Advances in Social Science, Education and Humanities Research, vol. 211, pp. 1-6, 2018.

[32] Idem.

[33] P.M. Herrera Molina, "Los convenios de doble imposición ante las libertades comunitarias (análisis de la jurisprudencia del TJCE)". Fiscalidad Internacional. Madrid, Spain: Instituto de Estudios Fiscales, pp. 1431-1452, 2010.

[34] K. Perrou, "Taxpayer Rights and Taxpayer Participation in Procedures Under the Dispute Resolution Directive," Intertax, vol. 47, no. 8/9, pp. 715-724, 2019.

[35] P. Neefs (December 2019). New ways in Luxembourg to better solve international tax disputes. KPMG Luxembourg Tax Alert. [Online]. Available: https://home.kpmg/lu/en/home/insights/2019/12/new-waysluxembourg-better-solve-international-tax-disputes.html

[36] P. Chico de la Cámara (October 2018). Resolución de litigios fiscales mediante ADRs en el ámbito de la Unión Europea. Legal Today - Fiscalidad Internacional. [Online]. Available: http://www.legaltoday.com/practicajuridica/fiscal/fiscalidad_internacional/resolucion-de-litigiosfiscales-mediante-adrs-en-el-ambito-de-la-union-europea

[37] S. Moreno González "Nuevas tendencias en materia de intercambio internacional de información tributaria: Hacia un mayor y más efectivo intercambio automático de información," Crónica Tributaria, no. 146, pp. 193-220, 2013.

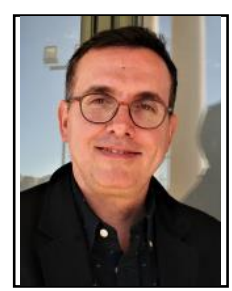

Benjamí Anglès Juanpere (Reus, Spain, 1971) Ph.D. Cum Laude in Tax Law, University Rovira i Virgili (Tarragona, Spain), in 2013. Master in Public Law, University Rovira i Virgili (Tarragona, Spain), in 2012. Master in Tax Law, University a Distancia de Madrid (Madrid, Spain), in 2011. And Degree in Law, University Oberta de Catalunya (Barcelona, Spain), in 2009.

Currently, he is a Tax Law Professor at the University Oberta de Catalunya (Barcelona, Spain), since 2015. Previously, he was Legal Adviser of a county council and Tax Inspector of a large municipality. Remarkable publications are: 1) "La fiscalidad de Bitcoin en España," Crónica Tributaria, no. 173, 2019 2) "La imposición local en el marco de la UE." Diálogos Judiciales en el sistema europeo de protección de derechos. Sevilla, Spain: Tirant lo Blanch, 2018, and 3) "Naturaleza y evolución de las PICAS en las Comunidades Autónomas de regimen común," Crónica Tributaria, no. 163, 2017. The current fields of research are tax and technology, tax procedures and local and regional taxes.

Dr. Anglès is member of the Spanish Financial and Tax Law Professors Network and member of the Eurasia Business and Economic Society (EBES). 